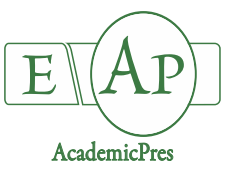

Nguyen KM et al. (2021)

Notulae Botanicae Horti Agrobotanici Cluj-Napoca

Volume 49, Issue 2, Article number 12306

DOI: $10.15835 /$ nbha 49212306

Research Article

\title{
Temperature-mediated shifts in chlorophyll biosynthesis in leaves of chlorophyll b-lacking rice (Oryza sativa L.)
}

\author{
Khiem Minh NGUYEN ${ }^{1,2,3,4}$, Zhi-Wei YANG ${ }^{5}$, Tin-Han SHIH ${ }^{1}$, Szu- \\ Hsien LIN ${ }^{1}$, Jun-Wei LIN ${ }^{1}$, Hoang Chinh NGUYEN ${ }^{4 * *}$, Chi-Ming \\ $\mathrm{YANG}^{1,2 *}$
}

\author{
${ }^{1}$ Biodiversity Research Center, Academia Sinica, Nangang, Taipei 115, Taiwan; nguyenminhkhiem@tdtu.edu.vn; \\ damnos@gmail.com;su043@yahoo.com.tw; cdward801029@hotmail.com; cmyang@gate.sinica.edu.tw (*corresponding author) \\ ${ }^{2}$ Biodiversity Program, Taiwan International Graduate Program, Academia Sinica and National Taiwan Normal University, Taipei \\ 115, Taiwan \\ ${ }^{3}$ Department of Life Science, National Taiwan Normal University, Taipei 106, Taiwan \\ ${ }^{4}$ Faculty of Applied Sciences, Ton Duc Thang University, Ho Chi Minh City 700000, \\ Vietnam; nguyenhoangchinh@tdtu.edu.vn $\left({ }^{* *}\right.$ co-corresponding author) \\ ${ }^{5}$ Taoyuan District Agricultural Research and Extension Station, Council of Agriculture, Taoyuan 327, \\ Taiwan; zwyang@tydais.gov.tw
}

\begin{abstract}
Extreme temperatures have become a threat to crop yields. To maintain plant growth and yield, chlorophyll (Chl) biosynthesis plays a crucial role in adaptation to temperature stress. This study investigated the influence of temperature on the biosynthesis and characteristics of pigments ( $\mathrm{Chl} a, \mathrm{Chl} b$, and carotenoids) in the leaves of Chl b-lacking mutant rice (Chlorina 1, chl) and wild-type rice (Norin No.8, wt). The chl showed thinner stacked grana caused by a decrease in thylakoid membranes per granum at $15^{\circ} \mathrm{C}$, whereas the destacked grana were observed at $35^{\circ} \mathrm{C}$ after $12 \mathrm{~h}$ incubation. However, the grana are stacked normally, along with the absence of Chl $b$, and a significantly decreased amount of Chl $a$ in both $w t$ and $c h 1$ were observed after heat stress exposure, demonstrating that light-harvesting complex II proteins are involved in grana stacking. Ch1 was sensitive to $15^{\circ} \mathrm{C}$ during the first $4 \mathrm{~h}$ of incubation but it subsequently adapted to the cold environment. In addition, there were no significant differences in the photosynthesis between wt and chl after $12 \mathrm{~h}$ incubation at $35^{\circ} \mathrm{C}$. Differentially expressed gene (DEGs) analysis revealed that GluRS expression decreased, which resulted in a decline in Chl biosynthesis in $w t$ and $\operatorname{ch} 1$ at $35^{\circ} \mathrm{C}$. At $8 \mathrm{~h}$ and $12 \mathrm{~h}$, there were no significant differences in the expression of DEGs involved in Chl biosynthesis and degradation between $w t$ and $c h 1$ at $15^{\circ} \mathrm{C}$. ALAD expression in $w t$ and $c h 1$ at $15^{\circ} \mathrm{C}$ decreased until it was undetectable. These findings suggested that $c h 1$ may adapt to temperatures ranging from $15^{\circ} \mathrm{C}$ to $35^{\circ} \mathrm{C}$.
\end{abstract}

Keywords: chlorophyll b-lacking mutant; grana; photosynthesis; temperature sensitivity

Received: 11 Mar 2021. Received in revised form: 30 Mar 2021. Accepted: 27 Apr 2021. Published online: 13 May 2021.

From Volume 49, Issue 1, 2021, Notulae Botanicae Horti Agrobotanici Cluj-Napoca journal uses article numbers in place of the traditional method of continuous pagination through the volume. The journal will continue to appear quarterly, as before, with four annual numbers. 


\section{Introduction}

Extreme temperatures caused by climate change, including cold stress and heat stress, affect the development, growth, and seasonal behaviors of plants, and can consequently impact crop yield (Raza et al., 2019; Ding et al., 2020). Under unsuitable growth temperature, thermomorphogenesis occurs and produces rapid changes in morphology. Vernalization and cold stratification processes can be observed as increases in flowering or seed germination under cold, moist temperatures, and may trigger cold acclimatization. In contrast, global warming frequently accelerates heat stress, which affects a part of the plant life cycle, particularly photosynthesis and carbon assimilation. High-temperatures have been found to decrease net photosynthetic rate, which is attributed to either stomatal or nonstomatal limitation (Hassan, 1999; Shangguan et al., 1999; Yordanov et al., 1999; Kadam et al., 2014). Rubisco activase, a heat-stable enzyme in higher plants involved in carbon assimilation and metabolism in the chloroplast stroma, was found to be inactivated at higher temperatures (Salvucci and Crafts-Brandner, 2004; Sharkey, 2005). Moreover, the key physiological indicator of heat stress was found to be loss and detachment of thylakoid membrane integrity (Gounaris et al., 1984; Semenova, 2004; Yamamoto et al., 2008; Ding et al., 2020). In addition, photosystem II (PS II) is the most heat-sensitive component within the chloroplast thylakoid membrane (Hu et al., 2020). The function of the electron transport, cleavage of the D1 reaction center-binding protein in PSII, and oxygenevolving complex were found to be altered by heat stress (Havaux and Tardy, 1997; Klimov et al., 1998; Yamane et al., 1998; Wahid et al., 2007; Allakhverdiev et al., 2008; Lin et al., 2013). Thus, the chloroplast was suggested as a key sensor to detect elevated temperatures because it is highly sensitive to damage from heat stress (Yu et al., 2012).

Chlorophylls (Chl) and carotenoid (Car) are the predominant plastid pigments with approximately $10^{9}$ tons of Chl being biosynthesized and degraded annually (Rüdiger, 1997; Eckhardt et al., 2004; Liu et al., 2007). Chl biosynthesis pathways have been well-documented (Nguyen et al., 2020) and are summarized in Figure 1. $\mathrm{Chl}$ is extremely important during photosynthesis because they play a central role in light absorption and energy transfer (Fromme et al., 2003). Chl $a$ is the most abundant pigment and presents in all higher plants. The second-most abundant pigment is $\mathrm{Chl} b$, which accounts for approximately one-quarter of the total chlorophyll in higher plants, and differs from $\mathrm{Chl} a$ only in the presence of a formyl group at the C-7 position instead of a methyl group. Chl a plays an important role in both light absorption and primary photochemical reactions, whereas $\mathrm{Chl} b$ is involved only in light absorption (Michel et al., 1983; Voitsekhovskaja and Tyutereva, 2015; Landi et al., 2020). Furthermore, $\mathrm{Chl} b$ also plays a major role in sustaining the accumulation of polypeptides associated with pigments and can serve as an intermediate to improve the efficiency of energy transfer between Chl $a$ and carotenoid (Car) (Bellemare et al., 1982; Terao et al., 1985; Allen et al., 1988). In addition, the binding of $\mathrm{Chl} b$ to the antenna proteins is needed for stable anchoring of the antenna complexes in thylakoid membranes (Voitsekhovskaja and Tyutereva, 2015).

Rice (Oryza sativa L.) is one of the most important food crops in the world. However, its yield is affected by the extreme temperatures caused by climate change and global warming (Horie, 2019). Under extreme temperatures, the photosynthetic machinery of rice undergoes modifications to adapt to the stress. Therefore, studies have focused on investigating the influence of temperature stress on the photosynthetic machinery of rice (Soda et al., 2018). Understanding the cold and heat tolerance in rice is one of the solutions for improving the rice yield (Cruz et al., 2013; Fahad et al., 2018). The breeding of mutated plants is achieved by effective treatments such as transfer-DNA insertion mutagenesis, physical mutagenesis (ionizing radiation), and chemical mutagenesis (ethyl methane sulphonate and EMS) (Liu et al., 2016). These mutations play an important role in evaluating plant life cycles, crop yield, plant characteristics, gene identification, and gene mapping genetics (Huang et al., 2014). Studies have reported that Chl-deficient mutants are light- (Hopkins et al., 1980; Markwell et al., 1986; Allen et al., 1988; Greene et al., 1988) and temperature-sensitive(Yang et al., 1990; Markwell and Osterman, 1992). Moreover, temperature sensitivity is a general characteristic of Chldeficient Melilotus alba(Yang et al., 1990) and Arabidopsis thaliana(Markwell and Osterman, 1992). Previous 
studies have introduced and elucidated the transcriptomic profiles and photosynthetic properties of $\mathrm{Chl} b$ lacking mutant rice (Chlorina 1, ch1) and wild-type rice (Norin No.8, wt) (Nguyen et al., 2020). However, the sensitivities under temperature stress on the $\mathrm{Chl}$ biosynthesis mechanism of $\mathrm{Chl} b$-lacking rice remains unclear. To further investigate these characteristics, the present study aimed to examine the influence of growth temperature on physiological characteristics and differentially expressed genes (DEGs) encoding 12 enzymes that play important role in $\mathrm{Chl}$ biosynthesis at $15^{\circ} \mathrm{C}$ and $35^{\circ} \mathrm{C}$ in both $w t$ and $c h 1$ rice. The interactions between $w t$ and $c h 1$ and temperature were also discussed in this work.

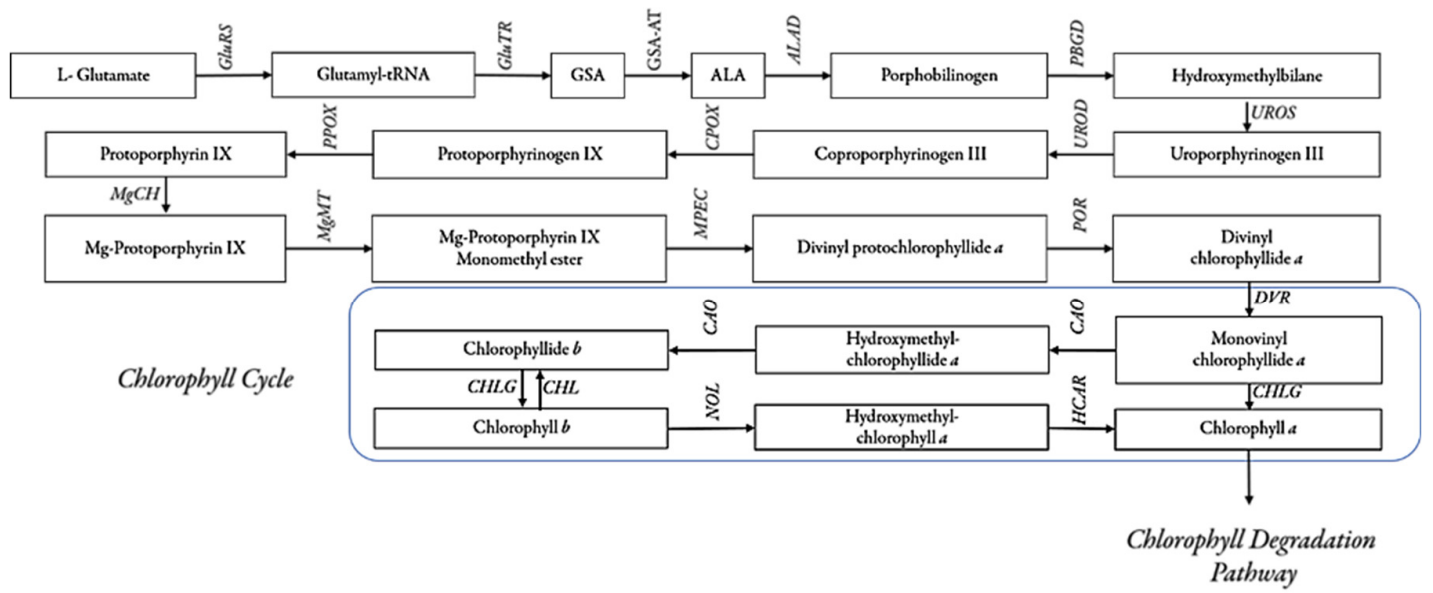

Figure 1. Chl biosynthesis pathway

Chl biosynthesis is composed of 3 separated sections: (1) Common pathway: The synthesis of protoporphyrin IX from the first committed precursor, 5-aminolevulinic acid (ALA). ALA is synthesized from L-glutamate via multiple reactions catalyzed by glutamyl-tRNA reductase (GluRS), glutamyl-tRNA reductase (GluTR), and glutamate 1semialdehyde aminotransferase (GSA-AT). Subsequently, intermediates, such as porphobilinogen, hydroxymethylbilane, uroporphyrinogen III, coproporphyrinogen III, protoporphyrinogen IX, and protoporphyrin IX, are produced through the reactions catalyzed by porphobilinogen synthase (ALAD), hydroxymethylbilane synthase (PBGD), uroporphyrinogen decarboxylase (UROD), coproporphyrinogen III oxidase (CPOX), and protoporphyrinogen oxidase (PPOX), respectively. (2) The Mg branch: Mg-chelatase $(\mathrm{MgCH})$ catalyzed to insert $\mathrm{Mg}^{2+}$ into protoporphyrin IX to form Mg-protoporphyrin IX. Subsequently, chlorophyllide $a$ is produced through multiple reactions catalyzed by different enzymes such as Mg-protoporphyrin IX methyltransferase ( $\mathrm{MgMT}), \mathrm{Mg}$ protoporphyrin IX monomethyl ester cyclase (MPEC), protochlorophyllide reductase (POR), and 3,4- divinyl protochlorophyllide a 9-vinyl reductase (DVR). (3) Chl cycle: This section includes the interconversion of Chl $a$ and $\mathrm{Chl} b$, which is catalyzed by chlorophyllide a oxygenase (CAO), chlorophyll synthase (CHLG), chlorophyll b reductase (NOL), and 7-hydroxymethyl chlorophyll a reductase (HCAR) (Masuda and Fujita, 2008; Lai et al., 2016; Nguyen et al., 2020).

\section{Materials and Methods}

\section{Plant materials and growth condition}

Seeds of $w t$ and $c h 1$ were graciously provided by Dr. Tomio Terao (Department of Applied Physiology, National Institute of Agrobiological Resources, Tsukuba Science City, Japan). The seeds were sown and observed in a growth chamber (Firstek, Taiwan), and the seedlings ( 3 plants) were grown for $42 \mathrm{~d}$ at $25^{\circ} \mathrm{C}$ at a relative humidity $(\mathrm{RH})$ of $\geq 80 \%$ and a $12 / 12$ photoperiod with the light intensity of $2000 \mu \mathrm{mol} \mathrm{s} \mathrm{m}^{-1}$. Then, sets of $w t$ and $c h 1$ plantlets were incubated at different temperatures $\left(15^{\circ} \mathrm{C}\right.$ or $\left.35^{\circ} \mathrm{C}\right)$ for $12 \mathrm{~h}$ under the same $\mathrm{RH}$, light intensity, and photoperiod. Leaves ( 3 leaves per plant) were then collected every $4 \mathrm{~h}$, frozen in liquid nitrogen, and kept at $-80^{\circ} \mathrm{C}$ for next uses. 
Pigments content assessment

Leaf samples (fresh leaves) were extracted using $80 \%(\mathrm{v} / \mathrm{v})$ acetone and homogenized using bullet blender tissue homogenizer (Next Advance Inc., New York, USA) at $4 \mathrm{~min}{ }^{\circ} \mathrm{C}$ for $5 \mathrm{~min}$. The absorbances of the extract were then measured at $663.6 \mathrm{~nm}, 646.6 \mathrm{~nm}$, and $440.5 \mathrm{~nm}$ using a UV-Visible spectrophotometer (Hitachi U2800, Tokyo, Japan) at room temperature to determine total Chl content, carotenoid (Car) content, and the ratio of $\mathrm{Chl} a$ to $\mathrm{Chl} b(\mathrm{Chl} a / b)$, respectively. The pigment contents were calculated, as follows (Yang et al., 1998):

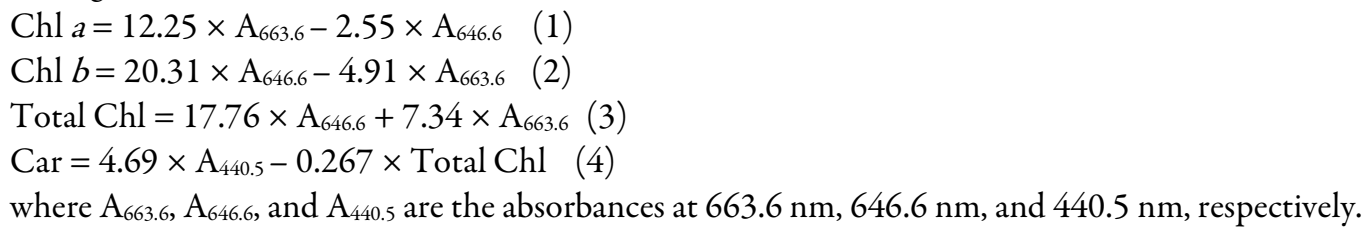

\section{Transmission electron microscopy}

The ultrastructure of $w t$ and chl leaf samples was observed using transmission electron microscopy. Each set of leaves were trimmed into small fragments $(0.5 \times 0.5 \times 0.5 \mathrm{~mm})$ and sample fragments were fixed in $2.5 \%$ glutaraldehyde at $4{ }^{\circ} \mathrm{C}$ for $24 \mathrm{~h}$ followed by in $1 \% \mathrm{OsO}_{4}$ for $2 \mathrm{~h}$. All fragment sets were then fixed up to $70 \mathrm{~nm}$ using a Leica EM UC6 ultramicrotome (Leica Microsystems GmbH, Wetzlar, Germany), stained using $1 \%(\mathrm{w} / \mathrm{v})$ lead citrate and 1\% (w/v) uranyl acetate (Spurr, 1969), and photographed using a Phillip Tecnai 12 transmission electron microscope (JEOL Ltd., Japan).

\section{Quantitative RT-PCR ( $q P C R)$}

Total RNA was extracted from wt and chl leaves using the RNeasy Plant Mini Kit (Qiagen, Hilden, Germany), following the manufacturer's instructions. Total RNA ( $\mu \mathrm{g})$ extracted from wt and chl was subjected to cDNA synthesis using a Transcriptor First Strand cDNA Synthesis Kit (Roche Diagnostic Systems, Branchburg, NJ, USA) and oligo (dT) primer. Primer sets were designed using Primer Premiere software version 6.0 (Pre- miereBiosoft, Palo Alto, USA) (Table 1). qPCR was performed using the StepOne Plus RealTime PCR system (Applied Biosystems, Life Technologies Inc, Italy) with iTaq Universal SYBR Green Supermix reagent (Bio-Rad, CA, USA) to analyze 12 genes involved in Chl biosynthesis and degradation (Nguyen et al., 2020). Relative gene expression values were calculated as $2^{-\Delta \mathrm{Ct}}$, where $\Delta \mathrm{Ct}$ was calculated as the difference between the cycle threshold $(\mathrm{Ct})$ of a target gene and the reference gene. The fold change in each gene in leaf tissues was calculated as $2^{-\Delta \mathrm{Ct}_{\text {mutant }}} / 2^{-\Delta \mathrm{Ct}_{\mathrm{t}}}$ wild-type.

Table 1. Primer sequences used in qPCR in this study

\begin{tabular}{|l|c|c|}
\hline \multicolumn{1}{|c|}{ Marker } & Forward sequence (5’-3') & Reverse sequence (5’-3’) \\
\hline$G L u R S$ & GCTCTCCGCTCAAGTGAATACC & GATCAGTCCAGTCCTCCACCTT \\
\hline$A L A D$ & GGCATGGGCTTCTTGATGAGG & CCAGAGCAACATCCGTGTAGAC \\
\hline$P B G D$ & GAAGGATTGACATTGCCGTCCA & GTCTACGCAGAGAAGCACTTCC \\
\hline$U R O D$ & GACGGCGTCATCCTGTTCTC & TGCGTAGAATCTTGAGCGACTC \\
\hline$C P O X$ & AAGCACCGTAATGAGCGTCG & TCAGTTGTTGCCATGCCTTGT \\
\hline$P O R$ & TCATCCTCGGCTCCATCACC & CTCCTGCATCGTCAGCATGTT \\
\hline$D V R$ & CAGGTTCATCAAGGTGCCGAT & CGTCATCTCGTCGCTGTACTC \\
\hline$C A O$ & GCATGGACTTCTGCTGGACAA & AGATGCCAGTGGTTGACAAGAC \\
\hline$H C B R$ & GCAGGAAGCAAGACATGGATGA & GCATTGGAGCAAGCCTGTCA \\
\hline$C H L G$ & GGGCACTGTTGTTAGCAGGG & GCCAATGTAGCTCGCACCAA \\
\hline$N O L$ & CACTGCTTCTCCTGGAATGGTC & GCAAGATCCTTGGTGGTGTCAA \\
\hline$M g C H$ & AAGATGGTTGCCGAACTGGATG & ATGTCCTGGAGCTGCTTCTCA \\
\hline UBQ10* & CTCATCTCCTCTCCTCGCATCA & CCACCAATCGGATCTAGCAACA \\
\hline
\end{tabular}




\section{Statistical analysis}

The pigment contents and relative gene expressions (qPCR results) of $w t$ and chl were statistically analyzed using least significant difference (LSD) $\mathrm{t}$-tests at $p \leq 0.05$. All tests were performed by SAS version 8.0 (Research Triangle Park, NC, USA).

\section{Results}

\section{Effects of temperature on pigment contents}

The 35 40 cm and 25 30 cm height wt and chl plantlets were obtained after 6 weeks incubation at 25 ${ }^{\circ} \mathrm{C}$, respectively. Each set of $w t$ and $c h 1$ plantlets was transferred to a growth chamber with a controlled temperature of $15^{\circ} \mathrm{C}$ (wt-15, ch1-15) or $35^{\circ} \mathrm{C}$ (wt-35, ch1-35) for $12 \mathrm{~h}$. The leaves were taken for analysis every $4 \mathrm{~h}$. The results showed that leaf coloration differed between wt and $c h 1$ at both $15^{\circ} \mathrm{C}$ and $35^{\circ} \mathrm{C}$. From $0-12 \mathrm{~h}$, the $w t$ leaves remained dark green to light green, whereas the chl leaves ranged from light green to yellow-green (Figure 2) at both $15^{\circ} \mathrm{C}$ and $35^{\circ} \mathrm{C}$.

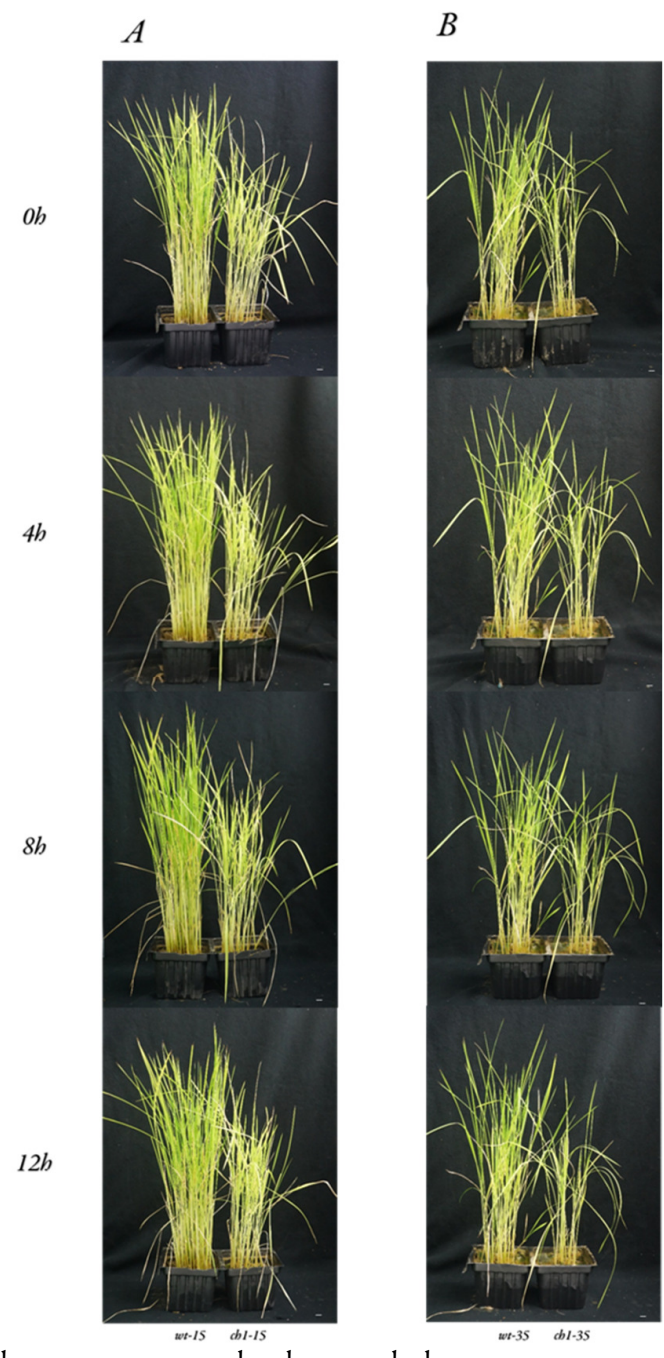

Figure 2. Effects of growth temperature on plantlet morphology

Changes in wild-type rice ( $w t-15, w t-35)$ and chl b-lacking rice (ch1-15, ch1-35) plantlets grown at (A) $15^{\circ} \mathrm{C}$ and (B) $35^{\circ} \mathrm{C}$ at $0 \mathrm{~h}, 4 \mathrm{~h}, 8 \mathrm{~h}$, and $12 \mathrm{~h}$ incubation. Bar $=1 \mathrm{~cm}$. 
The tip of $c h 1$ became dry compared to wt leaves after $12 \mathrm{~h}$ at $35^{\circ} \mathrm{C}$, whereas both $c h 1$ and $w t$ remained healthy at $15^{\circ} \mathrm{C}$. Overall, the wt leaves accumulated roughly twice the amount of total $\mathrm{Chl}$ as chl leaves at the start of incubation $(0 \mathrm{~h})$. Over $12 \mathrm{~h}$ at $15^{\circ} \mathrm{C}$, the total Chl content of wt-15 and ch $1-15$ decreased remarkably from $4.5 \mathrm{mg} \mathrm{g}^{-1}$ and $2.63 \mathrm{mg} \mathrm{g}^{-1}$ to $0.9 \mathrm{mg} \mathrm{g}^{-1}$ and $0.32 \mathrm{mg} \mathrm{g}^{-1}$, respectively. Total Chl also significantly decreased in wt-35 and ch $1-35$ at $35^{\circ} \mathrm{C}$, from $4.31 \mathrm{mg} \mathrm{g}^{-1}$ to $0.34 \mathrm{mg} \mathrm{g}^{-1}$ and from $2.66 \mathrm{mg} \mathrm{g}^{-1}$ to $0.17 \mathrm{mg} \mathrm{g}^{-1}$, respectively (Figure 3A). Meanwhile, Chl a content also decreased in all samples (Figure 3B). Chl $b$ was not detected in ch1 in any treatment over $12 \mathrm{~h}$, whereas $\mathrm{Chl} b$ significantly decreased in $w t$ before it became absent at $8 \mathrm{~h}$ (for 35 ${ }^{\circ} \mathrm{C}$ treatment) or $12 \mathrm{~h}$ (for $15^{\circ} \mathrm{C}$ treatment) (Figure 3C). Hence, $\mathrm{Chl} b$ was absent from all ch 1 leaves, leading to $\mathrm{Chl} a / b$ of $\infty$ over $12 \mathrm{~h}$ in both treatments, whereas the $\mathrm{Chl} a / b$ in $w t$ increased to $\infty$ at $12 \mathrm{~h}$ (for $15^{\circ} \mathrm{C}$ treatment) and $8 \mathrm{~h}$ (for $35^{\circ} \mathrm{C}$ treatment) (Table 2). However, the Car content accumulated in wt leaves was roughly twice to four times greater than that in $\operatorname{chl}$ at $0 \mathrm{~h}$. However, the Car content of chl-15 slightly increased from 0.42 to $0.45 \mathrm{mg} \mathrm{g}^{-1}$, while Car content in ch1-35 significantly dropped from 0.42 to $0.28 \mathrm{mg} \mathrm{g}$ ${ }^{1}$. Besides, the Car content of the $w t-15$ and $w t-35$ increased rapidly at $15^{\circ} \mathrm{C}\left(0.71 \mathrm{mg} \mathrm{g}^{-1}\right)$ and $35^{\circ} \mathrm{C}(0.67 \mathrm{mg}$ $\left.\mathrm{g}^{-1}\right)$, respectively (Figure 3D).

$A$

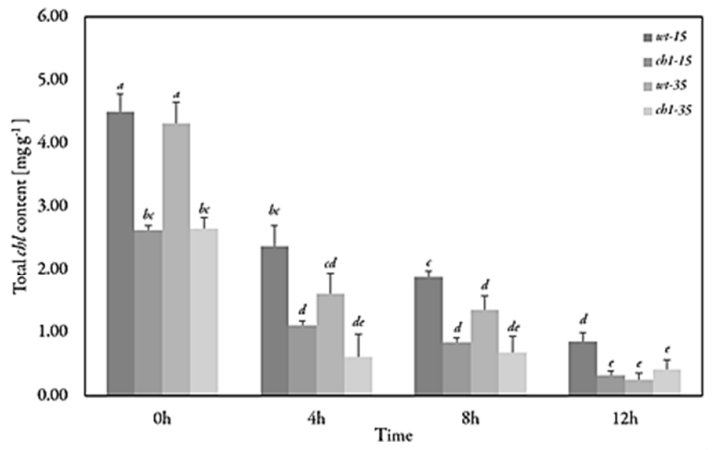

C

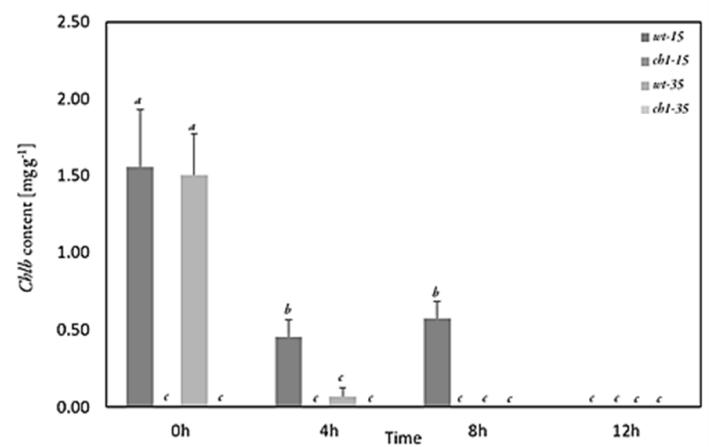

$B$

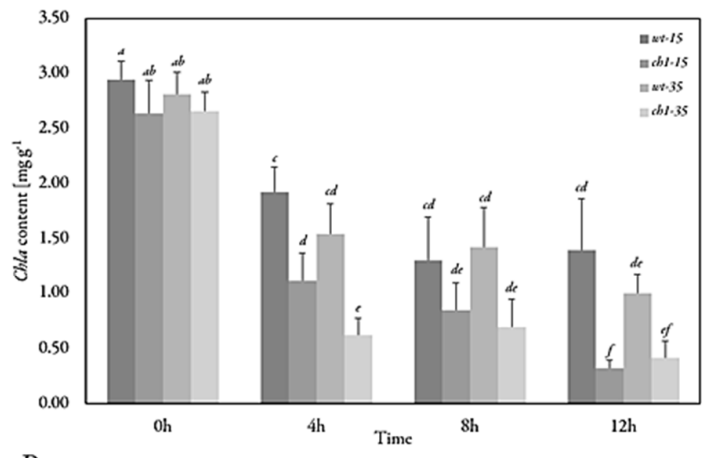

$D$

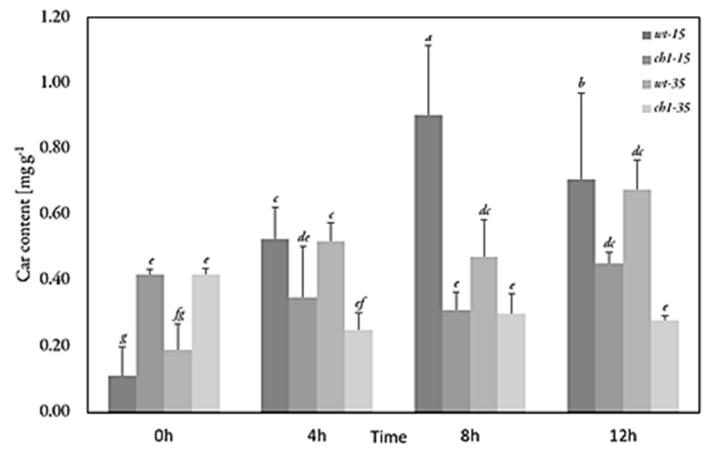

Figure 3. Effects of temperature on (A) total Chl, (B) Chl a, (C) Chl b, and (D) Car contents of wild-type rice (wt-15, wt-35) and $\mathrm{Chl} b$-lacking rice (ch1-15, ch1-35) grown at $15^{\circ} \mathrm{C}$ or $35^{\circ} \mathrm{C}$

Vertical bars show the standard deviations. Variables with the same letter mean no significant difference at $p \leq 0.05$ by LSD test.

Table 2. Chl a/b of wild-type and $\mathrm{Chl} \mathrm{b-lacking} \mathrm{rice} \mathrm{grown} \mathrm{at} 15^{\circ} \mathrm{C}$ or $35^{\circ} \mathrm{C}$

\begin{tabular}{|l|c|c|c|c|c|c|c|c|}
\hline \multirow{3}{*}{ Strain } & \multicolumn{9}{|c|}{$\mathrm{Chl} a / b$} \\
\cline { 2 - 9 } & \multicolumn{9}{|c|}{$15^{\circ} \mathrm{C}$} & \multicolumn{4}{c|}{$35^{\circ} \mathrm{C}$} & $4 \mathrm{~h}$ & $8 \mathrm{~h}$ & $12 \mathrm{~h}$ \\
\cline { 2 - 9 } & $0 \mathrm{~h}$ & $4 \mathrm{~h}$ & $8 \mathrm{~h}$ & $12 \mathrm{~h}$ & $0 \mathrm{~h}$ & 21.29 & $\infty$ & $\infty$ \\
\hline$w t$ & 1.89 & 4.20 & 2.27 & $\infty$ & 1.87 & $\infty$ & $\infty$ & $\infty$ \\
\hline chl & $\infty$ & $\infty$ & $\infty$ & $\infty$ & $\infty$ & $\infty$ & $\infty$
\end{tabular}

$w t$, wild-type rice (Norin No.8); ch1, chlorophyll $b$-lacking mutant (Chlorina 1). 


\section{Temperature effect on chloroplast development}

To examine the influences of temperature on chloroplast development, the chloroplast ultrastructures of $w t$ and chl grown at different temperatures were analyzed. At the start of both temperature treatments, chloroplasts from the mesophyll cells of $w t$ leaves exhibited a normal structure, including distinct thylakoid membranes and stromal lamellae with small starch granules and one or two plastoglobuli (Figure 4A). However, the chloroplasts of $c h 1$ leaves presented indistinct or absent stromal lamellae, indistinct thylakoid membranes, and abundant vesicles and plastoglobuli (Figure 4A). The stacked thylakoid grana of the chl leaves were also thinner than those of the wt leaves (Figure 4A). After $12 \mathrm{~h}$ incubation, destacked thylakoid grana were observed in ch1-35 (Figure 4C), while thinner and stacked thylakoid grana remained in ch1-15 (Figure $4 \mathrm{~B})$.

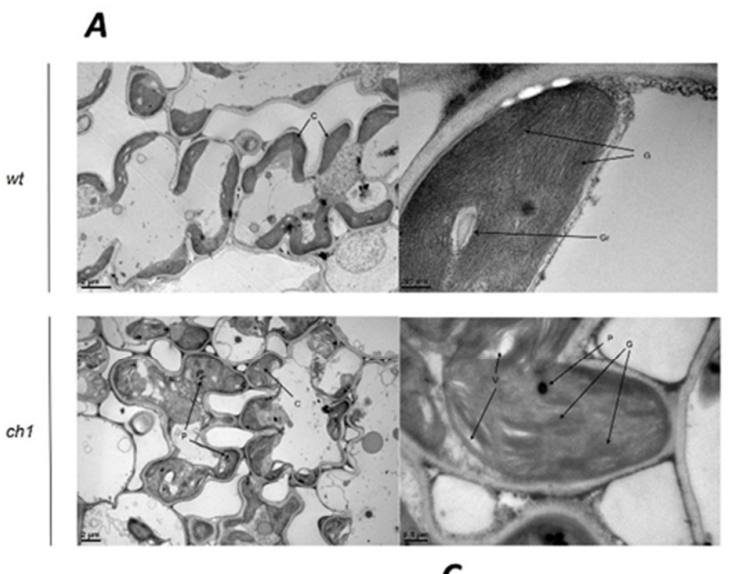

B
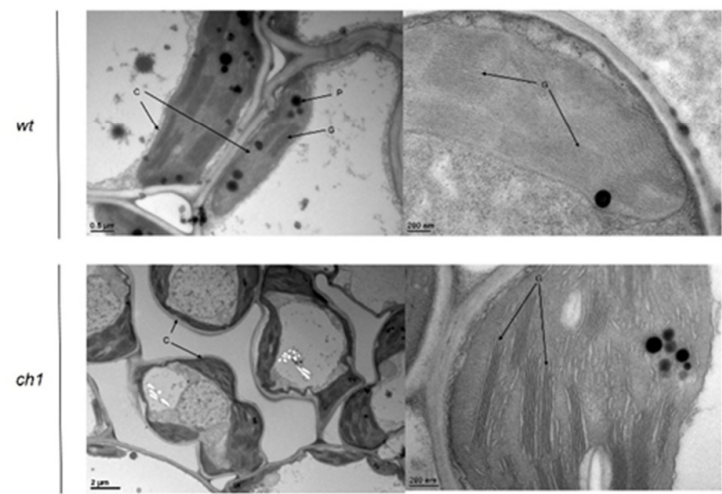

$\boldsymbol{C}$
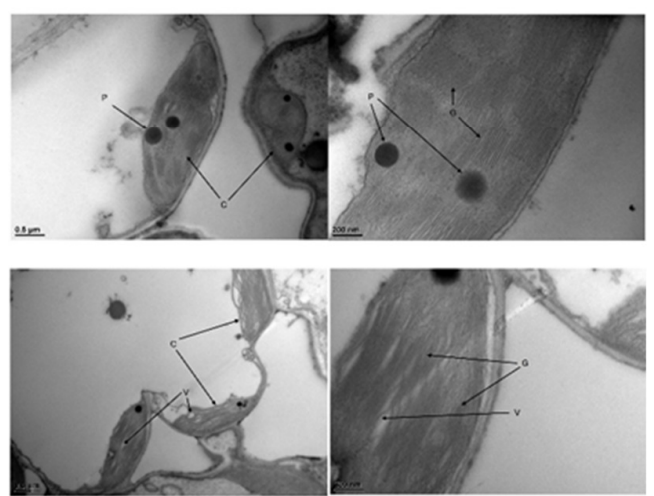

Figure 4. Effects of temperature on the chloroplast ultra-structures of wild-type and chlorophyll b-lacking rice

A. Normal chloroplast structure of $w t$ and abnormal chloroplast structure of chl, showing thinner thylakoid membranes and abundant plastoglobuli at $0 \mathrm{~h}$. Normal chloroplast structure of $w t$ and abnormal chloroplast structure of chl grown at (B) $15^{\circ} \mathrm{C}$ or $(\mathrm{C}) 35^{\circ} \mathrm{C}$ for $12 \mathrm{~h}$, showing indistinct thylakoid membranes and abundant plastoglobuli.

C, Chloroplast; G, grana; P, plastoglobuli; Gr, granulose, V, vacuole

Differentially expressed gene (DEGs) determined by $q P C R$

The expression of 11 of 12 genes related to Chl biosynthesis and degradation were analyzed by qPCR (Figure 5). Among the genes, $U R O D, C P O X$, and $N O L$ were significantly up-regulated in chl at $0 \mathrm{~h}$. Overall, the relative gene expression levels in the rice (both $w t$ and $c h 1$ ) grown at $35^{\circ} \mathrm{C}$ were higher than that of rice grown at $15^{\circ} \mathrm{C}$. $A L A D, C P O X, D V R$, and NOL were not detected after $4 \mathrm{~h}$ incubation at $15^{\circ} \mathrm{C}$ in ch 1-15. In contrast, the expression levels of $A L A D, C P O X, D V R$, and NOL did not differ significantly over $12 \mathrm{~h}$ at 35 ${ }^{\circ} \mathrm{C}$ in ch1-35. 


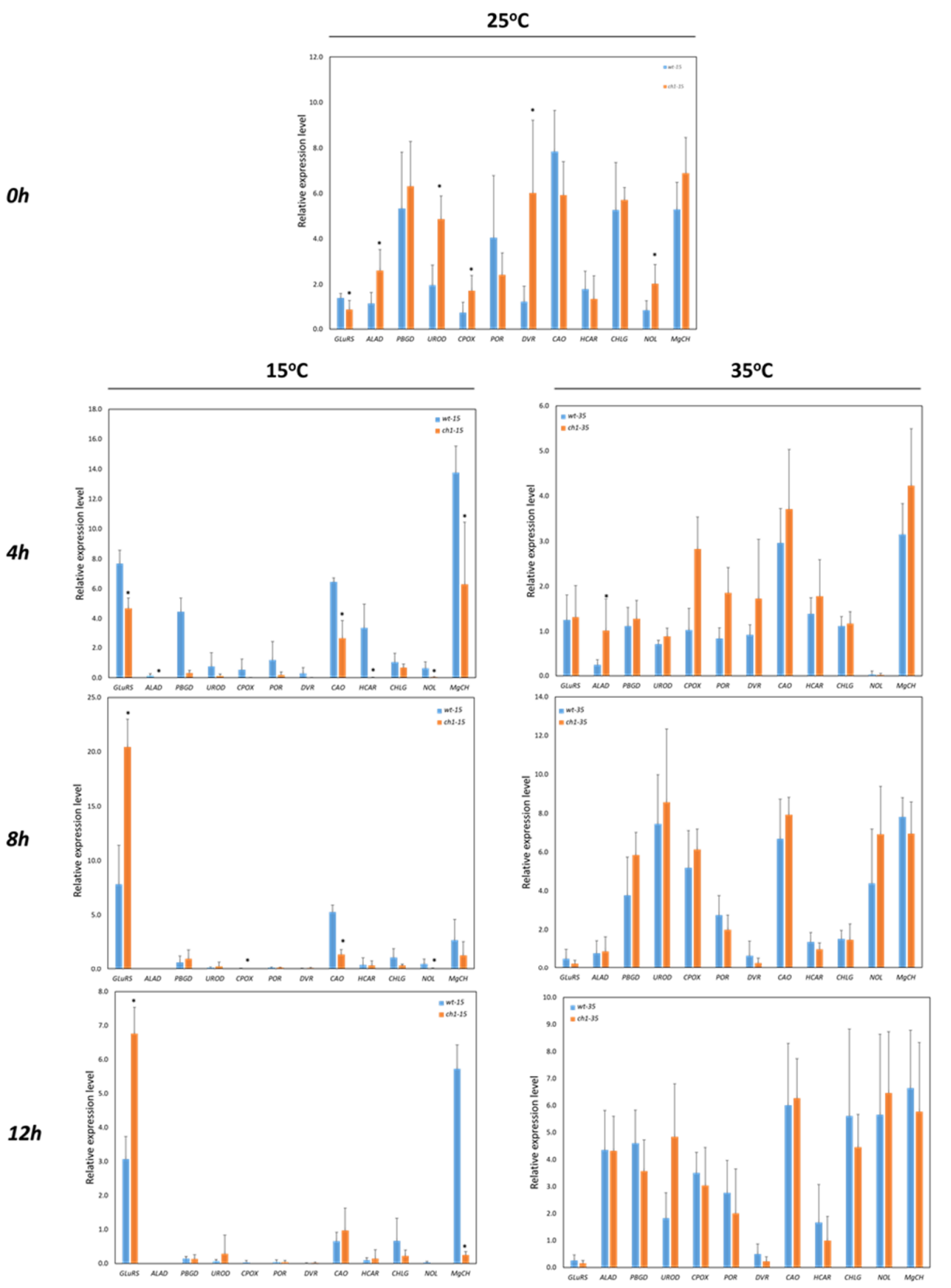

Figure 5. Expression of levels of 12 differentially expressed genes in wild-type and chlorophyll b-lacking rice

Gene expression was measured using quantitative real-time PCR. Asterisks $\left(^{*}\right)$ indicate significant differences in expression levels between the wt and $\operatorname{ch} 1(\mathrm{p} \leq 0.05)$

\section{Discussion}

Temperature stress results in changes in plant growth and physiology, and consequently, limits agricultural productivity (Kadam et al., 2014; Xin et al., 2015; Petrov et al., 2016). Both heat and cold stresses cause multi-step damages to the photosynthetic apparatus of plants. Cold stress has been shown to inhibit photosynthesis in the albino rice mutant (Allen and Ort, 2001). Nevertheless, the molecular mechanisms involving in the influences of temperature stress on plant development are not completely understood in Chl 
$b$-lacking mutant. In this study, $w t$ and $c h 1$ were grown at low and high temperatures to examine the responses of Chl $b$-lacking mutants to temperature stress. Compare to $w t$, chl plantlets were remarkably shorter and less healthy, with light green to yellow-green leaf coloration under both temperature treatments $\left(15^{\circ} \mathrm{C}\right.$ and $\left.35^{\circ} \mathrm{C}\right)$. Moreover, after $12 \mathrm{~h}$ incubation, the tips of ch1-35 leaves were dry compared to ch1-15 and wt-35, suggesting that high temperatures damaged plant development. This result is similar to that observed for heat-stress sensitive albino rice (Qiu et al., 2018).

When plants are exposed to extreme temperature, a high amount of reactive oxygen species (ROS) is produced, damaging the cellular structures and consequently causing plant senescence and death (Cheng et al., 2016). The peroxidation of membrane lipids caused by $\mathrm{O}_{2}$ and $\mathrm{H}_{2} \mathrm{O}_{2}$ resulted in destruction of chloroplast and degradation of plastid pigments (Zhao et al., 2011). In addition, chloroplast microstructure, photosynthetic metabolism, and energy production are damaged by cold and chilling conditions (Bilska and Sowiński, 2010), which inhibit photosynthesis and cause a serious threat to crop development. Under chilling stress, the efficiency of photosynthetic electron transfer in plants is drastically reduced, resulting in a burst of ROS that directly induces cellular oxidative damages and increases membrane rigidity (Nakashima et al., 2007; Chaves et al., 2009; Lawlor and Tezara, 2009; Xie et al., 2009). To respond to those damages, Car plays a vital role in the pathways that protect the photosynthetic apparatus from various extreme environmental factors. Under extreme heat conditions, Car mitigates the effects of intense heat by scavenging ROS produced during photooxidative stress (Strzałka et al., 2003). In addition, chloroplast plays a crucial role in photosynthetic machinery, where numerous metabolic reactions occur. However, it is effortlessly affected by environmental stressors, such as heat (Zhu, 2016). Heat stress causes partial changes in membrane fluidity, which is attributed to electron transport activity, and leads to photosynthesis inhibition (Raison et al., 1982; Havaux and Tardy, 1996; Murakami et al., 2000). In this study, total Chl decreased dramatically over $12 \mathrm{~h}$ in both temperature treatments, suggesting that temperature stress affects both wt and chl. In higher plants, photosynthesis temperature is usually based on natural atmosphere encountering. Consequently, the optimum temperature range typically matches the average daytime temperature (Berry and Bjorkman, 1980; Poorter, 2004). Additionally, the photosystems, the photosynthetic machinery, principally PSII with its oxygen-evolving complex, the ATP producing process, and the carbon metabolism process, are the three major stress-sensitive site (Aro et al., 1993; Bukhov and Carpentier, 2000; Nishiyama et al., 2005; Mohanty et al., 2007; Murata et al., 2007; Allakhverdiev et al., 2008). The analyses of the chloroplast ultrastructure revealed differences in thylakoid membrane structure between wt and $c h 1$ grown at both $15^{\circ} \mathrm{C}$ and $35^{\circ} \mathrm{C}$ for $12 \mathrm{~h}$. The wt chloroplasts possessed typical thylakoid membranes that were efficient for harvesting and converting light energy, whereas the $c h 1$ chloroplasts possessed abnormal thylakoid membranes. Similarly, chloroplasts of green bamboo leaves contain abundant thylakoid membranes, whereas the thylakoid membranes of Chl $b$-lacking bamboo leaves are converted into numerous abnormal vesicles (Yang et al., 2015a). In Anthurium andraeanum, the mesophyll cells of wild-type plants possess normal chloroplasts containing small starch granules and, thus, large gaps among stroma thylakoids (Yang et al., 2015b). The results obtained in the present study also demonstrated differences in the chloroplast structures of $w t$ and chl rice. The ultrastructure of ch1 (i.e. abundant plastoglobuli, indistinct thylakoid membranes, and reduced starch granules) indicated abnormal development and possibly a reduced accumulation of pigments, which would reduce light energy conversion efficiency and account for the coloration differences observed between $w t$ and ch1. The number of thylakoid membranes in ch1 significantly reduced, leading to thinner stacked grana. Therefore, the enhancement in Chl $a / b$ of $c h 1$ might reflect abnormal chloroplast development and function. In addition, heat stress typically leads to a loss of thylakoid membrane integrity, particularly the unstacking of thylakoid membranes (Gounaris et al., 1983; Semenova, 2004; Allakhverdiev et al., 2008).

In this work, the unstacked grana were observed in ch1-35 compared to ch1-15, suggesting that chloroplast development in chlorophyll $b$-lacking mutants is sensitive to high temperatures. The current study also found that grana stacking, along with an absence of $\mathrm{Chl} b$, is normal in both $w t$ and $c h 1$ at $15^{\circ} \mathrm{C}$ after 12 $\mathrm{h}$, whereas unstacked grana were observed in $c h 1$ at $35^{\circ} \mathrm{C}$. This result suggested that high temperatures affect 
chloroplast development in ch1. Studies have reported that grana stacking is affected both LHC II proteins and other factors (Nakatani and Baliga, 1985; Ouijja et al., 1988; Wood et al., 2019). The present study indicated that high temperatures might be one of the factors, along with LCHII, that affected grana stacking in rice.

This study examined the expression level of 12 important genes that code enzymes involved in Chl biosynthesis in rice (Nguyen et al., 2020). Those genes include GluRS, ALAD, PBGD, UROD, CPOX, POR, DVR, CAO, HCAR, CHLG, NOL, and MgCH. Over $12 \mathrm{~h}$, this study found no significant differences in the expression level of DEGs relative to Chl biosynthesis and degradation between $w t-35$ and $c h 1-35$. This result suggests that $c h 1$ is not sensitive to environmental temperatures ranging from $15^{\circ} \mathrm{C}$ to $35^{\circ} \mathrm{C}$. GluRS expression decreased in wt-35and ch1-35, and consequently, lead to a decrease in Chl biosynthesis in both wt-35and ch135. This is because at the early stage of Chl biosynthesis, GluRS encodes glutamyl-tRNA reductase, which catalyzes the conversion of glutamyl-tRNA into glutamate-semialdehyde (GSA), an important intermediate in the Chl biosynthesis cycle (Verkamp et al., 1992; Zhao et al., 2014). More specifically, ch1 was observed to be sensitive to $15^{\circ} \mathrm{C}$ at $4 \mathrm{~h}$ incubation but adapted to the cold environment at $8 \mathrm{~h}$ and $12 \mathrm{~h}$. There was no significant difference in the expression of DEGs related to $\mathrm{Chl}$ biosynthesis and degradation between $w t-15$ and $c h-15$ at $8 \mathrm{~h}$ and $12 \mathrm{~h}$. Moreover, even though GluRS expression rapidly increased, ALAD expression decreased until it could not be detected in wt-15 and ch1-15, suggesting that its production was blocked in the early stages of the experiment. Thus, total Chl of $w t-15$ and ch1-15 rapidly decreased over $12 \mathrm{~h}$ at $15^{\circ} \mathrm{C}$. This could be explained that ALAD encodes an aminolevulinic acid dehydratase, which catalyzes the reaction to condense two ALA to form porphobilinogen (Sassa, 1982). The intermediate porphobilinogen subsequently undergoes multiple enzymatic reactions to form Chl $a$ and $\mathrm{Chl} b$ (Willows and Hansson, 2003; Masuda and Fujita, 2008). This study suggests that low- and high-temperatures may affect DEGs associated with chloroplast development rather than Chl biosynthesis. Although many studies reported that Chl-deficient mutants of plants such as Morus alba and Arabidopsis thalianaare sensitive to temperatures (Yang et al., 1990; Markwell and Osterman, 1992), this study showed that $\mathrm{Chl} b$-lacking and wild-type rice adapted to environmental temperatures in ranging from $15^{\circ} \mathrm{C}-35^{\circ} \mathrm{C}$.

\section{Conclusions}

This study reported the biosynthesis and characteristics of pigments in the leaves of $w t$ and $c h 1$ under temperature stress. Ultrastructure analysis in chl revealed the thinner stacked grana at $15{ }^{\circ} \mathrm{C}$, whereas destacked grana were found at $30^{\circ} \mathrm{C}$ after $12 \mathrm{~h}$ incubation. Under temperature stress, $\mathrm{Chl} b$ is undetectable, whereas a significant deficiency in $\mathrm{Chl}$ a was found in both $w t$ and $c h 1$. Photosynthesis capacity was insignificantly different in $c h 1$ as compared to $w t$ after $12 \mathrm{~h}$ incubation at $35^{\circ} \mathrm{C}$. However, chl was sensitive

to $15^{\circ} \mathrm{C}$ during the first $4 \mathrm{~h}$ of incubation. This study suggested that chl may adapt to temperatures ranging from $15^{\circ} \mathrm{C}$ to $35^{\circ} \mathrm{C}$.

\section{Authors' Contributions}

Conceptualization: CMY, MKN, and THS; Methodology: CMY, MKN, and THS; Validation: MKN, SHL, JWL, HCN, and ZWY; Formal analysis: MKN, THS, and HCN; Investigation: MHK, SHL, JWL, and ZWY; Writing: MKN and HCN; Supervision: CMY; Project administration: MKN, HCN, and CMY. All authors read and approved the final manuscript. 
Nguyen KM et al. (2021). Not Bot Horti Agrobo 49(2):12306

\section{Acknowledgements}

This study was supported by the Taiwan International Graduate Program (TIGP) of National Taiwan Normal University (NTNU) and the Biodiversity Research Center (BRC) of the Academia Sinica, Taiwan.

\section{Conflict of Interests}

The authors declare that there are no conflicts of interest related to this article.

\section{References}

Allakhverdiev SI, Kreslavski VD, Klimov VV, Los DA, Carpentier R, Mohanty P (2008). Heat stress: an overview of molecular responses in photosynthesis. Photosynthesis Research 98:541. https://doi.org/10.1007/s11120-0089331-0

Allen DJ, Ort DR (2001). Impacts of chilling temperatures on photosynthesis in warm-climate plants. Trends in Plant Science 6:36-42. https://doi.org/10.1016/S1360-1385(00)01808-2

Allen KD, Duysen ME, Staehelin LA (1988). Biogenesis of thylakoid membranes is controlled by light intensity in the conditional chlorophyll $b$-deficient CD3 mutant of wheat. The Journal of Cell Biology 107:907. http://jcb.rupress.org/content/107/3/907.abstract

Aro EM, Virgin I, Andersson B (1993). Photoinhibition of photosystem II. Inactivation, protein damage and turnover. Biochimica et Biophysica Acta (BBA) - $\quad$ Bioenergetics 1143:113-134. https://doi.org/https://doi.org/10.1016/0005-2728(93)90134-2

Bellemare G, Bartlett SG, Chua NH (1982). Biosynthesis of chlorophyll $a / b$-binding polypeptides in wild type and the chlorina $\mathrm{f} 2$ mutant of Barley. Journal of Biological Chemistry 257:7762-7767. https://doi.org/10.1016/S00219258(18)34446-6

Berry J, Bjorkman O (1980). Photosynthetic response and adaptation to temperature in higher plants. Annual Review of Plant Physiology 31:491-543. https://doi.org/10.1146/annurev.pp.31.060180.002423

Bilska A, Sowiński P (2010). Closure of plasmodesmata in maize (Zea mays) at low temperature: a new mechanism for inhibition of photosynthesis. Annals of Botany 106:675-686. https://doi.org/10.1093/aob/mcq169

BukhovNG, Carpentier R (2000). Heterogeneity of photosystem II reaction centers as influenced by heat treatment of barley leaves. Physiologia Plantarum 110:279-285. https://doi.org/10.1034/j.1399-3054.2000.110219.x

Chaves MM, Flexas J, Pinheiro C (2009). Photosynthesis under drought and salt stress: regulation mechanisms from whole plant to cell. Annals of Botany 103:551-560. https://doi.org/10.1093/aob/mcn 125

Cheng XX, Yu M, Zhang N, Zhou ZQ, Xu QT, Mei FZ, Qu LH (2016.) Reactive oxygen species regulate programmed cell death progress of endosperm in winter wheat (Triticum aestivum L.) under waterlogging. Protoplasma 253:311-327. https://doi.org/10.1007/s00709-015-0811-8

Cruz RPda, Sperotto RA, Cargnelutti D, Adamski JM, de FreitasTerra T, Fett JP (2013). Avoiding damage and achieving cold tolerance in rice plants. Food and Energy Security 2:96-119. https://doi.org/https://doi.org/10.1002/fes3.25

Ding Y, Shi Y, Yang S (2020). Molecular regulation of plant responses to environmental temperatures. Molecular Plant 13:544-564. https://doi.org/https://doi.org/10.1016/j.molp.2020.02.004

Eckhardt U, Grimm B, Hörtensteiner S (2004). Recent advances in chlorophyll biosynthesis and breakdown in higher plants. Plant Molecular Biology 56:1-14. https://doi.org/10.1007/s11103-004-2331-3

Fahad S, Adnan M, Hassan S, Saud S, Hussain S, Wu C, Huang J (2018). Rice responses and tolerance to high temperature. In: Advances in Rice Research for Abiotic Stress Tolerance. Woodhead Publishing, pp 201-224. https://doi.org/10.1016/B978-0-12-814332-2.00010-1

Fromme P, Melkozernov A, Jordan P, Krauss N (2003). Structure and function of photosystem I: interaction with its soluble electron carriers and external antenna systems. FEBS Letters 555:40-44. https://doi.org/10.1016/S00145793(03)01124-4 
Gounaris K, Brain ARR, Quinn P, Williams WP (1984). Structural reorganisation of chloroplast thylakoid membranes in response to heat-stress. Biochimica et Biophysica Acta (BBA) - Bioenergetics 766:198-208. https://doi.org/10.1016/0005-2728(84)90232-9

Gounaris K, Brain APR, Quinn PJ, Williams WP (1983). Structural and functional changes associated with heat-induced phase-separations of non-bilayer lipids in chloroplast thylakoid membranes. FEBS Letters 153:47-52. https://doi.org/https://doi.org/10.1016/0014-5793(83)80117-3

Greene BA, Allred DR, Morishige DT, Staehelin LA (1988). Hierarchical response of light harvesting chlorophyllproteins in a light-sensitive chlorophyll $b$-deficient mutant of maize. Plant Physiology 87:357364.http://www.ncbi.nlm.nih.gov/pmc/articles/PMC1054757/

Hassan I (1999). Effects of $\mathrm{O}_{3}$ and drought stress on growth, yield and physiology of tomatoes (Lycopersicon esculentum Mill. Cv Baladey). Gartenbauwiessenschaft 76:122-135.

Havaux M, Tardy F (1997). Thermostability and photostability of photosystem ii in leaves of the chlorina-f2 barley mutant deficient in light-harvesting chlorophyll $a / b$ protein complexes. Plant Physiology 113:913-923. https://doi.org/10.1104/pp.113.3.913

Havaux M, Tardy F (1996). Temperature-dependent adjustment of the thermal stability of photosystem II in vivo: possible involvement of xanthophyll-cycle pigments. Planta 198:324-333. https://doi.org/10.1007/BF00620047

HopkinsWG, Hayden DB, Neuffer MG (1980). A light-sensitive mutant in maize (Zea mays L.) I. Chlorophyll, chlorophyll-protein and ultrastructural studies. Zeitschrift Für Pflanzenphysiologie 99:417-426. https://doi.org/https://doi.org/10.1016/S0044-328X(80)80157-7

Horie T (2019). Global warming and rice production in Asia: modeling, impact prediction and adaptation. Proceedings of the Japan Academy, Series B, 95:211-245. https://doi.org/10.2183/pjab.95.016

$\mathrm{Hu}$ S, Ding Y, Zhu C (2020). Sensitivity and responses of chloroplasts to heat stress in plants. Frontiers in Plant Science 11:375. https://doi.org/10.3389/fpls.2020.00375

Huang J, Qin F, Zang G, Kang Z, Zou H, Hu F, Yue C, Li X, Wang G (2013). Mutation of OsDET1 increases chlorophyll content in rice. Plant Science 210: 241-249. https://doi.org/10.1016/j.plantsci.2013.06.003

Huang S, Liu Z, Li D, Yao R, Meng Q, Feng H (2014). Screening of Chinese cabbage mutants produced by 60Co $\gamma$-ray mutagenesis of isolated microspore cultures. Plant Breeding 133:480-488. https://doi.org/10.1111/pbr.12166

Kadam NN, Xiao G, Melgar RJ, Bahuguna RN, Quinones C, Tamilselvan A, Jagadish KSV (2014). Agronomic and physiological responses to high temperature, drought, and elevated $\mathrm{CO}_{2}$ interactions in cereals. Advances in Agronomy 127:111-156. https://doi.org/10.1016/B978-0-12-800131-8.00003-0

Klimov V, Baranov S, Allakhverdiev S (1998). Bicarbonate protects the donor side of photosystem II against photoinhibition and thermoinactivation. FEBS Letters 418:243-246. https://doi.org/10.1016/S00145793(97)01392-6

Lai YC, Wang SY, Gao HY, Nguyen KM, Nguyen CH, Shih MC, Lin KH (2016). Physicochemical properties of starches and expression and activity of starch biosynthesis-related genes in sweet potatoes. Food Chemistry 199:556-564. https://doi.org/10.1016/j.foodchem.2015.12.053

Landi M, Zivcak M, Sytar O, Brestic M, Allakhverdiev SI (2020). Plasticity of photosynthetic processes and the accumulation of secondary metabolites in plants in response to monochromatic light environments: A review. Biochimica et Biophysica Acta (BBA) - Bioenergetics 1861:14813. https://doi.org/10.1016/j.bbabio.2019.148131

Lawlor DW, Tezara W (2009) Causes of decreased photosynthetic rate and metabolic capacity in water-deficient leaf cells: a critical evaluation of mechanisms and integration of processes. Annals of Botany 103:561-579. https://doi.org/10.1093/aob/mcn244

Lin YH, Pan KY, Hung CH, Huang HE, Chen CL, Feng TY, Huang LF (2013). Overexpression of ferredoxin, PETF, enhances tolerance to heat stress in Chlamydomonas reinhardtii. International Journal of Molecular Sciences 14:20913-20929. https://doi.org/10.3390/ijms141020913

Liu R, Dong X, Gu W, Yu L, Jin W, Qu Y, Li W (2016). Variation in the phenotypic features and transcripts of thermosensitive leaf-color mutant induced by carbon ion beam in Green wandering jew (Tradescantia fluminensis). Scientia Horticulturae 213:303-313. https://doi.org/https://doi.org/10.1016/j.scienta.2016.11.001

Liu W, Fu Y, Hu G, Si H, Zhu L, Wu C, Sun Z (2007). Identification and fine mapping of a thermo-sensitive chlorophyll deficient mutant in rice (Oryza sativa L.). Planta 226:785-795. https://doi.org/10.1007/s00425-007-0525-Z

Markwell J, Osterman JC (1992). Occurrence of temperature-sensitive phenotypic plasticity in chlorophyll-deficient mutants of Arabidopsis thaliana L. Plant Physiology 98:392-394. https://doi.org/10.1104/pp.98.1.392 
Markwell JP, DankoSJ, Bauwe H, Osterman J, Gorz HJ, Haskins FA (1986). A temperature-sensitive chlorophyll $b$ deficient mutant of sweetclover (Melilotus alba). Plant Physiology 81:329-334. https://doi.org/10.1104/pp.81.2.329

Masuda T, Fujita Y (2008) Regulation and evolution of chlorophyll metabolism. Photochemical \& Photobiological Sciences 7:1131-1149. https://doi.org/10.1039/B807210H

Michel H, Tellenbach M, Boschetti A (1983). A chlorophyll b-less mutant of Chlamydomonas reinhardii lacking in the light-harvesting chlorophyll ab-protein complex but not in its apoproteins. Biochimica et Biophysica Acta (BBA) - Bioenergetics 725:417-424. https://doi.org/10.1016/0005-2728(83)90182-2

Mohanty P, Allakhverdiev S, Murata N (2007). Application of low temperature during photoinhibition allows characterization of individual steps in photodamage and repair of photosystem II. Photosynthesis Research 94:217-224. https://doi.org/10.1007/s11120-007-9184-y

Murakami Y, Tsuyama M, Kobayashi Y, Kodama H, Iba K (2000). Trienoic fatty acids and plant tolerance of high temperature. Science 287:476-479. https://doi.org/10.1126/science.287.5452.476

Murata N, Takahashi S, Nishiyama Y,Allakhverdiev SI (2007). Photoinhibition of photosystem II under environmental stress. Biochimica et Biophysica Acta (BBA) - Bioenergetics 1767:414-421. https://doi.org/https://doi.org/10.1016/j.bbabio.2006.11.019

Nakashima K, Tran LP, Van Nguyen D, Fujita M, Maruyama K, Todaka D, Ito Y, Hayashi N, Shinozaki K, YamaguchiShinozaki K (2007). Functional analysis of a NAC-type transcription factor OsNAC6 involved in abiotic and biotic stress-responsive gene expression in rice. Plant Journal 51:617-630. https://doi.org/10.1111/j.1365313X.2007.03168.X

Nakatani HY, Baliga V (1985). A clover mutant lacking the chlorophyll $a$ - and $b$-containing protein antenna complexes. Biochemical and Biophysical Research Communications 131:182-189. https://doi.org/https://doi.org/10.1016/0006-291X(85)91787-5

Nguyen MK, Shih TH, Lin SH, Huang WD, Yang CM (2020). Transcription analysis of chlorophyll biosynthesis in wildtype and chlorophyll b-lacking rice (Oryza sativa L.). Photosynthetica 58:702-711. https://doi.org/10.32615/ps.2020.022

Nishiyama Y, Allakhverdiev SI, Murata N (2005). Inhibition of the repair of Photosystem II by oxidative stress in cyanobacteria. Photosynthesis Research 84:1-7. https://doi.org/10.1007/s11120-004-6434-0

Ouijja A, Farineau N, Cantrel C, Guillot-Salomon T (1988). Biochemical analysis and photosynthetic activity of chloroplasts and Photosystem II particles from a barley mutant lacking chlorophyll $b$. Biochimica et Biophysica Acta (BBA) - Bioenergetics 932:97-106. https://doi.org/https://doi.org/10.1016/0005-2728(88)90143-0

PetrovK, Lyubov V, Dudareva L, Nokhsorov V, Perk A, Chepalov V, Zulfugarov I (2016). The role of plant fatty acids in regulation of the adaptation of organisms to the cold climate in cryolithic zone of Yakutia. Journal of Life Science 26:519-530. https://doi.org/10.5352/JLS.2016.26.5.519

Poorter H (2004). Physiological plant ecology. Annals of Botany 93:616-617. https://doi.org/10.1093/aob/mch084

Qiu Z, Kang S, He L, Zhao J, Zhang S, Hu J, Zhu L (2018). The newly identified heat-stress sensitive albino 1 gene affects $\begin{array}{lllll}\text { chloroplast development in } & \text { 267:168-179. }\end{array}$ https://doi.org/https://doi.org/10.1016/j.plantsci.2017.11.015

RaisonJK, Roberts JKM, Berry JA (1982). Correlations between the thermal stability of chloroplast (thylakoid) membranes and the composition and fluidity of their polar lipids upon acclimation of the higher plant, Nerium oleander, to growth temperature. Biomembranes 688:218-228. https://doi.org/https://doi.org/10.1016/00052736(82)90597-1

RazaA, Razzaq A, Mehmood SS, ZouX, Zhang X, Lv Y, Xu J (2019). Impact of climate change on crops adaptation and strategies to tackle its outcome: A review. Plants 8:34. https://doi.org/10.3390/plants8020034

Rüdiger W (1997). Chlorophyll metabolism: From outer space down to the molecular level. Phytochemistry 46:11511167. https://doi.org/10.1016/S0031-9422(97)80003-9

Salvucci ME, Crafts-Brandner SJ (2004). Relationship between the heat tolerance of photosynthesis and the thermal stability of rubisco activase in plants from contrasting thermal environments. Plant Physiology 134:1460-1470. https://doi.org/10.1104/pp.103.038323

Sassa S (1982). Delta-Aminolevulinic acid dehydratase assay. Enzyme 28:133-145. https://doi.org/10.1159/000459097 Semenova GA (2004). Structural reorganization of thylakoid systems in response to heat treatment. Photosynthetica 42:521-527. https://doi.org/10.1007/S11099-005-0008-z 
Shangguan Z, Shao M, Dyckmans J (1999). Interaction of osmotic adjustment and photosynthesis in winter wheat under soil drought. Journal of Plant Physiology 154:753-758.https://doi.org/https://doi.org/10.1016/S0176$1617(99) 80254-5$

Sharkey TD (2005). Effects of moderate heat stress on photosynthesis: importance of thylakoid reactions, rubisco deactivation, reactive oxygen species, and thermotolerance provided by isoprene. Plant, Cell \& Environment 28:269-277. https://doi.org/10.1111/j.1365-3040.2005.01324.x

Soda N, Gupta BK, Anwar K, Sharan A, Govindjee, Singla-Pareek SL, Pareek A (2018). Rice intermediate filament, OsIF, stabilizes photosynthetic machinery and yield under salinity and heat stress. Scientific Reports 8:4072. https://doi.org/10.1038/s41598-018-22131-0

Strzałka K, Kostecka-Gugała A, Latowski D (2003). Carotenoids and environmental stress in plants: significance of carotenoid-mediated modulation of membrane physical properties. Russian Journal of Plant Physiology 50:168173. https://doi.org/10.1023/A:1022960828050

Terao T, Yamashita A, Katoh S (1985). Chlorophyll $b$-deficient mutants of rice. 1 . Absorption and fluorescence spectra and chlorophyll $a / b$ ratios. Plant and Cell Physiology 26:1361-1367. https://doi.org/10.1093/oxfordjournals.pcp.a077036

Verkamp E, Jahn M, Jahn D, Kumar A, Soll D (1992). Glutamyl-tRNA reductase from Escherichia coli and Synechocystis 6803: Gene structure and expression. Journal of Biological Chemistry 267:8275-8280. https://doi.org/10.1016/S0021-9258(18)42438-6

Voitsekhovskaja O V, Tyutereva E V (2015). Chlorophyll $b$ in angiosperms: Functions in photosynthesis, signaling and ontogenetic regulation. Journal of Plant Physiology 189:51-64. https://doi.org/10.1016/j.jplph.2015.09.013

Wahid A, Gelani S, Ashraf M, Foolad MR (2007). Heat tolerance in plants: an overview. Environmental and Experimental Botany 61:199-223. https://doi.org/https://doi.org/10.1016/j.envexpbot.2007.05.011

Wood WHJ, Barnett SFH, Flannery S, Hunter CN, Johnson MP (2019). Dynamic thylakoid stacking is regulated by LHCII phosphorylation but not its interaction with PSI. Plant Physiology 180:2152-2166. https://doi.org/10.1104/pp.19.00503

Xie G, Kato H, Sasaki K, Imai R (2009). A cold-induced thioredoxin h of rice, OsTrx23, negatively regulates kinase activities of OsMPK3 and OsMPK6 in vitro. FEBS Letters 583:2734-2738. https://doi.org/10.1016/j.febslet.2009.07.057

Xin C, Hou R, Wu F, Zhao Y, Xiao H, Si W, Guo J (2015). Analysis of cytosine methylation status in potato by methylation-sensitive amplified polymorphisms under low-temperature stress. Journal of Plant Biology 58:383390. https://doi.org/10.1007/s12374-015-0316-1

Yamamoto Y, Aminaka R, Yoshioka M, Khatoon M, Komayama K, Takenaka D, Yamamoto Y (2008). Quality control of photosystem II: impact of light and heat stresses. Photosynthesis Research 98:589-608. https://doi.org/10.1007/s11120-008-9372-4

YamaneY, Kashino Y, Koike H, Satoh K (1998). Effects of high temperatures on the photosynthetic systems in spinach: oxygen-evolving activities, fluorescence characteristics and the denaturation process. Photosynthesis Research 57:51-59.https://doi.org/10.1023/A:1006019102619

Yang CM, Osterman JC, Markwell J (1990). Temperature sensitivity as a general phenomenon in a collection of chlorophyll-deficient mutants of sweetclover (Melilotus alba). Biochemical Genetics 28:31-40. https://doi.org/10.1007/BF00554819

Yang HY, Xia XW, Fang W, Fu Y, An MM, Zhou MB (2015a). Identification of genes involved in spontaneous leaf color variation in Pseudosasa japonica. Genetics and Molecular Research 14:11827-11840. http://dx.doi.org/10.4238/2015.October.2.16

Yang Y, Chen X, Xu B, Li Y, Ma Y, Wang G (2015b). Phenotype and transcriptome analysis reveals chloroplast development and pigment biosynthesis together influenced the leaf color formation in mutants of Anthurium andraeanum 'Sonate'. Frontiers in Plant Science 6:139.https://doi.org/10.3389/fpls.2015.00139

Yordanov I, Velikova V, Tsonev T (1999). Influence of drought, high temperature, and carbamide cytokinin 4-pu-30 on photosynthetic activity of bean plants. 1. Changes in chlorophyll fluorescence quenching. Photosynthetica 37:447457. https://doi.org/10.1023/A:1007163928253

Yu HD, Yang XF, Chen ST, Wang YT, Li JK, Shen Q, Guo FQ (2012). Downregulation of chloroplast RPS1 negatively modulates nuclear heat-responsive expression of HsfA2 and its target genes in Arabidopsis. PLoS Genetics 8:e1002669. https://doi.org/10.1371/journal.pgen.1002669 
Zhao A, Fang Y, Chen X, Zhao S, Dong W, Lin Y, Gong W, Liu L (2014). Crystal structure of Arabidopsis glutamyltRNA reductase in complex with its stimulator protein. Proceedings of the National Academy of Science 111:6630-6635. https://doi.org/10.1073/pnas.1400166111

Zhao X, Nishimura Y, Fukumoto Y, Li J (2011). Effect of high temperature on active oxygen species, senescence and photosynthetic properties in cucumber leaves. Environmental and Experimental Botany 70:212-216. https://doi.org/10.1016/j.envexpbot.2010.09.005

Zhu JK (2016). Abiotic stress signaling and responses in plants. Cell 167:313-324. https://doi.org/10.1016/j.cell.2016.08.029
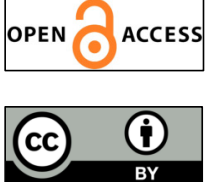

The journal offers free, immediate, and unrestricted access to peer-reviewed research and scholarly work. Users are allowed to read, download, copy, distribute, print, search, or link to the full texts of the articles, or use them for any other lawful purpose, without asking prior permission from the publisher or the author.

License - Articles published in Notulae Botanicae Horti Agrobotanici Cluj-Napoca are Open-Access, distributed under the terms and conditions of the Creative Commons Attribution (CC BY 4.0) License. (C) Articles by the authors; UASVM, Cluj-Napoca, Romania. The journal allows the author(s) to hold the copyright/to retain publishing rights without restriction. 